\title{
IAMJ
}

INTERNATIONAL

AYURVEDIC

MEDICAL JOURNAL

ISSN: 2320-5091

Impact Factor: 6.719

\section{THE CHANGING PERCEPTION OF INDIAN CONSUMERS TOWARDS AYURVEDA AMID COVID-19 PANDEMIC: OPPORTUNITY FOR INDIAN MANUFACTURERS}

\author{
Vidur Sahni ${ }^{1}$, Vandana Chandhoke ${ }^{2}$ \\ ${ }^{1}$ Student, Class XII, and Director, ENSHIP - Entreprenuership Club, Delhi Public School, R.K. Puram, Delhi, India \\ ${ }^{2}$ Head, Department of Political Science and Legal Studies, Delhi Public School, R.K. Puram, Delhi, India
}

Corresponding Author: sahnividur@gmail.com

\section{https://doi.org/10.46607/iamj3909082021}

(Published Online: August 2021)

Open Access

(C) International Ayurvedic Medical Journal, India 2021

Article Received: 28/07//2021 - Peer Reviewed: 06/08/2021 - Accepted for Publication: 07/08/2021

\section{Check for updates}

\section{ABSTRACT}

In the wake of the COVID-19 pandemic, the reliance of people on Ayurvedic Science has relatively in-creased. This may be due to the limited availability of COVID-19 vaccine(s) in both rural and urban India. Even in territories where adequate vaccine availability is ensured by the government, significant apprehensions related to the efficacy of the vaccine continue to hover in the minds of Indian consumers. This specific pattern of consumer behavior across India encouraged Indian consumers to turn to ayurvedic medicines as an alternative to boost their immunity seek protection from Covid-19. However, the longstanding resistance towards Ayurvedic Medicine in the past due to their lower efficacy and other factors continues to act as a significant obstruction for firms trying to increase their customer base during the pandemic. The present paper interview uses the CEO of leading ayurvedic manufacturers to unravels how firms are ag-aggressively leveraging the power of marketing to reduce the resistance prevalent toward Ayurveda among Indian consumers. Specifically, the paper discusses all the dimensions of the marketing mix and its subsequent role in reducing the resistance to give it a holistic outlook. The paper concludes by highlighting the implications for Ayurvedic firms who are looking for a complete transformation into vibrant health and medical system.

Keywords: Covid-19, Ayurveda, Indian Consumers, Marketing Mix 


\section{INTRODUCTION}

Ayurveda is one of the world's oldest holistic healing systems. It was developed more than 3,000 years ago in India. It is based on the notion that health and wellness depend on a delicate balance between mind, body, and spirit. This healing system is directed at promoting good health, rather than fighting a disease. However, the field has advanced towards curing specific health problems. ${ }^{1}$ The Indian Ayurveda market was valued at INR 300 billion in 2018 and is estimated to touch INR 710.87 billion by 2024, growing at a compound annual growth rate (CAGR) of $\sim 16.06$ per cent, during the forecast period (2019-2024). ${ }^{2}$ Increased awareness about the healthy lifestyle, consumer drift towards the consumption of chemicalfree natural products and favourable government initiatives were some of the prominent factors that contributed to the expansion of the Ayurveda industry in India. ${ }^{2}$ Some of the popular ayurvedic product categories available in the Indian market include personal care products, food and beverages, household products and healthcare products. ${ }^{2}$ The global reception of traditional practices of herbal and Ayurveda treatments has acted as a catalyst to promote Ayurveda tourism in India. The Indian Ayurvedic market is dominated by some of the major players including Dabur India Limited, Emami Limited, Patanjali Ayurveda Limited, The Himalaya Drug Company, Sandu Pharmaceuticals Limited, and Shahnaz Ayurveda Private Limited. ${ }^{2}$ Ayurveda is observing a resurgence in India because a significant proportion of the population has embraced it as a way of life in contrast to the earlier perception of Ayurveda as an alternative area of medicine. In the series of efforts, the Government of India instituted a dedicated Ministry of AYUSH (Ayurveda, Yoga, Unani, Siddha and Homoeopathy) in November 2014 to promote the country's indigenous alternative medicines and education and research concerning them. ${ }^{3}$ Despite its long history and legacy in the Indian culture, Indian consumers still showed high reluctance towards Ayurvedic products. Some of the prominent factors that contribute to consumer resistance include the perceived low quality of the ayurvedic products. Indian consumers feel that Ayurvedic medicines offer lower efficacy. Further, in Ayurveda, herbal and medicinal plants are the principal ingredients and the limited availability of high-quality plants led to lowering the quality of Ayurvedic products. The nonadherence to quality standards by the majority of the Indian players often led to lapses in the quality control procedures and process compliances, thereby, lowering the consumer trust towards Ayurvedic products.

However, during the COVID-19 pandemic, the dependence of consumers on Ayurvedic Science has relatively increased. This may be due to the limited availability of COVID-19 vaccine(s) in both rural and urban India. Even in regions where adequate vaccine availability is ensured by the government, concerns related to the efficacy of the vaccine continue to hover in the minds of Indian consumers. This specific pattern of consumer behaviour across India encouraged Indian consumers to turn to ayurvedic medicines as an alternative to boost their immunity seek protection from Covid-19. Taking advantage of this situation, organisations are aggressively changing their marketing strategy to reduce consumer resistance. ${ }^{4}$ This present study understands this drift by interviewing the CEO, Kashmir Herbal Remedies (KHR), one of India's fastest growing ayurvedic manufacturers.

\section{RESEARCH CONTEXT AND SCOPE}

The study selected Kashmir herbal remedies (KHR), one of India's leading Ayurvedic manufacturers as the scope of research.

\section{About KHR}

With the great vision and vast knowledge of the most ancient system of medicines, Vaidya Raj Bhola Nath Dilawari made a humble beginning by establishing KHR over half a century ago. The present team at KHR led by the current CEO (Satyan Dilawari) carried forward his father's legacy. As of 2021, KHR had successfully developed over 350 unique preparations ( $\mathrm{Pa}$ tent \& Classical), designed to treat common ailments. 
KHR used one of the most modernised plants for making herbal remedies, wellness products and extracts while ensuring their full efficacy and purity. The R\&D efforts at KHR were primarily focused on two dimensions, namely, reformulations of existing traditional products and also deriving new product formulations. In the former category, the focus was on improving the existing products to further ameliorate product acceptance. The latter dimension of R\&D involved focused clinical research on traditional herbs and other ingredients to form new preparations. The consistent focus of KHR on product innovation was driven by the intent to stay way ahead of the competition and to identify other product lines. Quality control at each step of the value chain was another core pillar of KHR. From the procurement of high-quality raw material (ingredients) to following the highly advanced manufacturing practices, KHR had employed a dedicated team to look after the quality control. The efforts enabled KHR to bring a lot of product standardization into their operations. KHR caters to both rural and urban India. KHR had intensively focused on growing its presence in the Indian rural market since a significant population was deprived of basic hospital infrastructure including access to allopathic medicines. The reliance of the rural population on herbal medication further acted as a catalyst for KHR to increase its presence in rural India. Ever since its existence, KHR has persisted in selling its products at as low a price as possible. The focus had always been on the economies of production which had been the main reason for the economic prices, a factor the management had always considered most essential in the field of healthcare products. The current marketing priorities involve urban India and the export market as well, with new products developed especially for these markets and up-gradation of the older established products. KHR is one of the leading suppliers to various govt. organizations in India engaged in the purchase of herbal products

\section{RESEARCH METHOD: QUALITATIVE STUDY INTERVIEW}

The paper adopted interviews as a research method. ${ }^{5}$ The authors interviewed the CEO of KHR, Satyan
Dilawari, to understand the change in marketing strategy during the pandemic when consumers are turning towards Ayurvedic medicines to bolster their immunity against Covid-19. The interview focussed on all dimensions of marketing mix i.e. product, price, place and promotion for holistic evaluation of the new strategy. ${ }^{6}$

\section{DISCUSSION}

\section{Product}

KHR manufactured close to 350 herbal products used for curing different allergic problems, brain tribulations, liver troubles, hair problems, cough, detoxifiers, digestives and many more. The new product development at KHR was driven by the dynamic market interest and need. For instance, he recalled the transformation KHR made during the previous year by diligently following the intense demand for immunity boosters created by Covid-19. Satyan concluded his experience on new product development especially during the Covid-19 as "understanding and meeting the unmet needs of society was imperative for business success". Satyan believed that out of total 14 product lines manufactured by KHR (Appendix A), 7 product lines including (Digestive Care, Rheumatic Care, General Tonic, Female Care, Aphrodisiac, Eye, Ear Care, and Respiratory Care) were doing satisfactorily in terms of market share, customer acceptance and revenue contribution. However, he felt that for the remaining 7 product lines, the intensity of consumer resistance was higher in the Pre-Covid 19 times. Satyan believed that the majority of Indian consumers do not reject outright, rather they show a strong tendency of postponing and opposing the use the Ayurvedic medicines. He recalled several of his interactions with end consumers, who procrastinated over the use of KHR medicines for a long time. In the post-Covid-19 times, Satyan concluded that product bundling could be an appropriate aggressive strategy to reduce consumer resistance. This implies organisations including KHR must bundle their highest and lowest selling product lines to reduce the overall resistance perception towards Ayurveda. The product bundling 
would enable consumers to at least try the Ayurvedic products. ${ }^{7}$ The trust built towards Ayurvedic products especially immunity boosters would put a cascading impact on other Ayurvedic products.

\section{Price}

In the Pre-Covid 19 times, KHR considered both costs of production and prices of competing products while deciding the overall pricing strategy for its products. ${ }^{8}$ The use of high-quality raw materials often made KHR products slightly expensive as compared to the prices of the competing products. Satyan always believed delivering customer value in medicine was of utmost importance. There had been instances in KHR's history when because of the use of high-quality ingredients, the final product often resulted in higher costs. After adding the desired margins of intermediary channels, the final price was even higher than similar products promoted by bigger players operating in the Indian Ayurveda market. Because of the higher price, KHR had faced consumer resistance in such instances. In the Post Covid-19 times, Satyan concluded that organisations need to shift from cost and competition-based pricing to value-based pricing ${ }^{9}$ to reduce consumer resistance. ${ }^{10}$

\section{Promotion}

In the Pre-Covid-19 times, the majority of the ayurvedic companies including KHR followed an array of promotional strategies to create brand and product awareness in the target markets. Specifically, KHR relied on the prescription and dispensing promotional strategy. KHR's medical representatives periodically made presentations to the doctors and assured them about the efficacy of KHR drugs and influenced them to further prescribe them to their respective patients. The medical representatives also regularly interacted, educated and convinced chemists about the fast-acting effectiveness of the KHR medicines. Thus the targets for 'prescription' promotional strategy were allopathic, ayurvedic, homoeopathic doctors and chemists. This conventional marketing strategy was working quite well for KHR. 'Dispensing' involved hospitals and nursing homes stocking medicines in their inhouse stores and thus removing the intermediary chemist.
In the Post Covid-19 times, ayurvedic companies including KHR should aggressively pursue OTC (over the counter) push strategy. E-mail and social media campaigns on popular mediums namely Facebook, Linked In and Twitter to enhance the image of its products and KHR's visibility should also hold the key to reduce consumer resistance.

\section{Place}

In the Post Covid-19 times, Satyan recommends ayurvedic companies including KHR to incentivise channel partners so that shelf space in retail stores could be increased, thus eventually encouraging channel partners to promote ayurvedic products among end consumers.

\section{CONCLUSION}

The paper contributes to the body of literature by unravelling how manufacturers are using Covid-19 as an opportunity to transform the perception of Indian consumers towards general Ayurvedic medicines. The discussion highlights specific key insights about how to effectively re-orient all 4P's of the marketing mix (product, price, place, promotion) during these unprecedented times to change consumer behaviour. The paper leaves key managerial implications by suggesting how to effectively leverage the power of marketing to gain a competitive advantage.

\section{REFERENCES}

1. Kelli Miller, "What Is Ayurveda?, WebMD, March 20, 2021, https://www.webmd.com/balance/guide/ayurvedic-treatments accessed 29 Jun. 21

2. Research and Markets, "India Ayurveda Industry Outlook 2019-2024 - Market Size \& Growth Forecasts, Product Launches, Competitive Landscape, Cision, Feb 19, 2020, https://www.prnewswire.com/news-releases/india-ayurveda-industry-outlook-2019-2024--market-size--growth-forecasts-product-launches-competitive-landscape-301007651.html accessed 29 Jun. 21.

3. IBEF, "India emerging as a global wellness and ayurveda hub", India Brand Equity Foundation, Feb 08, 2021, https://www.ibef.org/blogs/india-emerging-as-aglobal-wellness-and-ayurveda-hub accessed June 30, 2021.

4. Kleijnen M, Lee N, Wetzels M. An exploration of consumer resistance to innovation and its antecedents. 
Journal of economic psychology. 2009 Jun 1;30(3):344-57.

5. Schoenberger E. The corporate interview as a research method in economic geography. The Professional Geographer. 1991 May 1;43(2):180-9.

6. Borden NH. The concept of the marketing mix. Journal of advertising research. 1964 Jun 2;4(2):2-7.

7. Reinders MJ, Frambach RT, Schoormans JP. Using product bundling to facilitate the adoption process of radical innovations. Journal of Product Innovation Management. 2010 Dec;27(7):1127-40.

8. Shin J, Sudhir K, Yoon DH. When to "fire" customers: Customer cost-based pricing. Management Science. 2012 May;58(5):932-47.

9. Hinterhuber A. Towards value-based pricing-An integrative framework for decision making. Industrial marketing management. 2004 Nov 1;33(8):765-78.

10. Penaloza L, Price LL. Consumer resistance: a conceptual overview. ACR North American Advances. 1993.

\section{Appendix A: Product Portfolio at KHR}

Digestive Care:

- Acidnok- Excellent for Hyperacidity

- Ayunzyme- For strengthening intestines

- Tripolar Aloe Vera ras- Purifies blood and glorifies skin

- Dysentil Plus- Relief from colicky pain

- Ulsacid- Reduces acidity

- Digestion- Cure all ailments connected with the digestive system

- Hepta 10- Regulates bile, rekindles hunger

- Krimin- Regulates bowels

\section{Rheumatic Care:}

- Asthisand- Maintains texture and strength of bones

- Nirgundi- Helps in improving blood circulations, pain reliever

- Relieved Oil- Useful in morning stiffness

- Vatantak- Reduces pain, Relives excruciating pain/discomfort

- Rheumalin Oil- Nourishes and strengthens neuromuscular systems and regulates easy movements of muscles and joints.

- Rheumalin Tablets- Alleviates pain, swelling, tenderness of stiff joints and improves grip strength.

- Rheumalin Gold- Relieves contraction and stiffness of joints
- Rheumalin Ointment- Relaxes muscles and reduces swelling, stiffness and tenderness in a stiff neck.

\section{General Tonic:}

- Aloevera Amla Mix- Regulates, protects and promotes the functioning of important body organs like the liver, spleen, kidney and intestines.

- Herbo Stamin- Meets the complete protein needs healthy growing children and adults and provides adequate carbohydrates.

- Amla Ras- Natural richest source of vitamin C with great therapeutic values and is known as Rasayana.

- Chyawanprash- improves memory and learning ability

- Aloevera- It's a potent and effective whole body rejuvenator.

- Feral Forte- Raises haemoglobin levels in the blood and helps maintain proper oxygenation of the body, especially in pregnancy.

- Shiplax- Enhances physical strength and provide vigour in rundown conditions.

- Energyn Forte- Helps reshape and revitalize the body, reduces stress, maintains youthfulness and supports proper functioning.

\section{Female Care:}

- Femomyn- Exhibits anti-inflammatory and antispasmodic action, regulates the normal menstrual flow and improves mood.

- Calfirol C- Highly effective for pregnant women, weak children and anaemic persons.

- Leucocide- exhorts anti-microbial and astringent actions on the mucous membrane of genital system and help street leucorrhoea

- Mensol- replenishes iron stores, stimulates endometrium, improves uterine circulation

\section{Aphrodisiac:}

- Shilajit- known as the destroyer of weakness, helps in improving physical endurance, vigour and vitality

- Mentex Forte Gold- improve health and energy level, promotes calmness and helps gain and retain power. 
- Sanjiwani Tila- its regular use in short enjoyable sexual life.

- Dhatupoustic Leha- it is a nutritive tonic and cures weakness.

\section{Heart Care:}

- Ashwagandha Arjun- it is a superb tonic for cardiovascular health, it helps in preventing early ageing and rejuvenates the whole body.

- Hridyeshu- supports cardiovascular and arterial health and reduces peripheral vascular resistance.

\section{Eye, Ear Care:}

- Catramide- protects eyes from all pollution and adverse environment of modern life.

- Karan Sudha- support healthy immune system functioning and promote outer, middle and inner ear health and balance.

\section{Skin Care:}

- Dermacid- naturally strengthens the immune system, and protects against pathogens and varied skin manifestations.

- Dermacid ointment- prevents the spreading of bacterial and fungal infections and helps the skin tissue to recover.

\section{Anti-Pyretic:}

- Giloy- works well against general and seminal debilities and in the management of diabetes.

- Remedin-it is a unique formulation for all kinds of fevers. It helps to destroy all kinds of bacteria and toxins in the blood.

\section{Urinary and Diabetic Care:}

- Karela Jamun- is extremely helpful in reducing blood sugar levels.

- Pramehin-release stress increases performance and long-lasting endurance and increases its perm count.

- Dicure- helps in pancreatic functions, stimulates the immune system and helps in general weakness and fatigue.

- Prostol-it promotes the flow of urine, cools and soothes the membrane of the urinary tract and nourishes the kidney.

- Calcurid- Acts on strangury, urinary infections, burning micturition.
- Madhumerin- boosts pancreas function, corrects glucose metabolism and arrests the ageing process of cells.

\section{Piles Care:}

- Pilease- corrects the digestive system, reduces intra-abdominal pressure.

- Pilend- reduces anal swelling and heals anorectal region.

\section{Memory And Stress:}

- Braino Forte- sharpens memory and intelligence and increases the functional efficiency of the brain.

- Allayu- has this soothing effect on the central nervous system.

- Memori- relieves emotional distress and anxiety and correct nervous debility, inappropriate behaviour.

- Brahmi And Shankhpushpi- it is useful for improving IQ levels mental clarity, confidence and memory recall.

\section{Respiratory:}

- $\operatorname{Cosin} \mathrm{X}$ - prevent chronic cough, relieves muscle spasm and cures productive as well as dry cough.

- Somoco- releases cough and respiratory discomfort and soothes the throat and irritated bronchial.

- Coughcil- it eliminates throat inflammation and then shows fractions of mouth. Relives respiratory discomfort and suits throat and irritated bronchial.

\section{Hair Care:}

- Kesha- nurses and smoots hair cuticle, make hair long, strong and thick and stops further hair loss

\section{Source of Support: Nil Conflict of Interest: None Declared}

How to cite this URL: Vidur Sahni \& Vandana Chandhoke: The Changing Perception Of Indian Consumers Towards Ayurveda Amid Covid-19 Pandemic: Opportunity For Indian Manufacturers. International Ayurvedic Medical Journal \{online\} 2021 \{cited August 2021\} Available from: http://www.iamj.in/posts/images/upload/1850_1855.pdf 